\title{
Percent of Building Density (PBD) of Urban Environment: A multi-index Approach Based Study in DKI Jakarta Province
}

\author{
Ardiansyah, Revi Hernina, Weling Suseno, Faris Zulkarnain, Ramadhani Yanidar and \\ Rokhmatuloh Rokhmatuloh
}

Received: 2018-08-01/ Accepted:2018-11-05/ Published online: 2018-12-31

(c) 2018 Faculty of Geography UGM and The Indonesian Geographers Association

\begin{abstract}
This study developed a model to identify the percent of building density (PBD) of DKI Jakarta Province in each pixel of Landsat 8 imageries through a multi-index approach. DKI Jakarta province was selected as the location of the study because of its urban environment characteristics. The model was constructed using several predictor variables i.e. Normalized Difference Built-up Index (NDBI), Soil-adjusted Vegetation Index (SAVI), Normalized Difference Water Index (NDWI), and surface temperature from thermal infrared sensor (TIRS). The calculation of training sample data was generated from high-resolution imagery and was correlated to the predictor variables using multiple linear regression (MLR) analysis. The R values of predictor variables are significantly correlated. The result of MLR analysis shows that the predictor variables simultaneously have correlation and similar pattern to the PBD based on high-resolution imageries. The Adjusted R Square value is 0,734 , indicates that all four variables influences predicting the PBD by $73 \%$.
\end{abstract}

Keywords: Percent of building density; multi-index approach; urban environment; Landsat 8, DKI Jakarta Province

\begin{abstract}
Abstrak Penelitian ini berusaha membangun sebuah model untuk identifikasi persentase kepadatan bangunan pada tiap pixel landsat 8 di Provinsi DKI Jakarta melalui pendekatan multi indeks. Provinsi DKI Jakarta dipilih sebagai lokasi penelitian karena mewakili karakteristik dari lingkungan perkotaan. Model rasio lahan terbangun dibangun dari beberapa variabel prediktor yaitu Normalized Difference Built-up Index (NDBI), Soil-adjusted Vegetation Index (SAVI), Normalized Difference Water Index (NDWI), dan suhu permukaan (termal radian). Perhitungan persentase kepadatan bangunan didapatkan dari pengamatan visual citra resolusi tinggi yang kemudian dikorelasikan dengan dengan variabel-variabel prediktor menggunakan analisis linier berganda. Nilai $R$ dari variabel-variabel prediktor menunjukan bahwa terdapat korelasi yang signifikan. Hasil perhitungan dari analisis linier berganda menunjukan bahwa variabel-variabel prediktor secara Bersama-sama memiliki korelasi dan kesamaan pola dengan perhitungan persentase kepadatan bangunan yang berasal dari citra resolusi tinggi. Nilai adjusted $R$ square adalah 0,734 yang mana menunjukan bahwa seluruh variabel prediktor mempengaruhi model persentase kepadatan bangunan sebesar $73 \%$.
\end{abstract}

Kata kunci: Persen kepadatan bangunan; pendekatan multi-indeks; lingkungan urban; Landsat 8, Provinsi DKI Jakarta

\section{Introduction}

Over the last two decades, remote sensing data has been used for calculating the built-up area and becomes a popular scientific tool [Zha, et al., 2003; Maktav et al., 2005; Bhatti \& Tripathi, 2014]. The commonly used index is Normalized Difference Built-up Index or NDBI. NDBI is widely used for mapping the built-up area existence by using remote sensing imagery This algorithm only considers the 2 bands that reflected the rate and generates only the index value [Zha et al., 2003]. The output using NDBI is only representing an index of yields rather than the ratio or

@ 2018 by the authors. Licensee Indonesian Journal of Geography, Indonesia.
This article is an open access article distributed under the terms and conditions of the Creative Commons
Attribution(CC BY NC) licensehttps://creativecommons.org/licenses/by-nc/4.0/.
Ardiansyah, Revi Hernina and Rokhmatuloh Rokhmatuloh
Faculty of Mathematics and Natural Science, Universitas Indonesia, Indonesia
Weling Suseno
PT Infimap Geospasial Sistem, Indonesia
Faris Zulkarnain
Center for Applied Geography Research, Universitas Indonesia
Ramadhani Yanidar
Faculty of Landscape Architecture and Environmental Technology, Trisakti University
Correspondent e-mail: ardiansyah1708@gmail.com

percent of building density (PBD). PBD refers to the percentage of built-up area to the entire area or the area of the building footprint to the total plot area.

As mention before that NDBI is a widely used algorithm for estimating urban built-up area but it has limitation in particular for separating built-up area and bare land [He, et al., 2010; As-syakur et al., 2012; Varshney, 2013; Hidayati et al., 2018]. The principle of this algorithm is for sharpening objects with the ratio between Mid-Infrared (MIR) and Near Infrared (NIR) bands. Based on its characteristics, the widespread built-up area reflects MIR higher than the NIR wave. However, in some cases, dry vegetation or soil has similar characteristics as MIR reflectance values much higher than NIR waves [Gao, 1996a].

Some research has been conducted to integrate multi-index to improve model accuracy of NDBI. [Masek et al., 2000] identified land constructed in the City of Washington DC through a time series vegetation index which is Normalized Difference Vegetation Index (NDVI). Another previous research has been conducted by [Xu, 2007], which 
identified land-use by using 3 variables approach i.e. NDBI, Soil-adjusted Vegetation Index (SAVI), and Normalized Difference Water Index (NDWI). $\mathrm{Xu}$ [2007] is combining NDBI, SAVI, and NDWI to delineate built-up area and non-built area from Landsat, as the result is show that the new composite image is more distinguishable than the original separate band. In addition, [Waqar et al., 2012] utilizes the NDBI, Normalized Built-up Index (NBI), and NDWI index to interpret the built-up area. Both studies only interpret the built-up area by comparing the radiometric of the index without producing a built-up area ratio model. NDBI is a common rapid method for identifying the built-up area but it has limitation to differentiate between built-up area and bare land [As-syakur et al., 2012]. Using only NDBI allows the occurrence of noise thereby minimizing accuracy. For minimizing this limitation, this research is using Thermal Infrared Sensor (TIRS) to differentiate it. TIRS is able to delineate the boundary between builtup area and bare land clearly [Rasul et al., 2018; Yu et al., 2014]. NDWI dan SAVI is powerful to detect builtup area with vegetation grounds [Ao Yong \& Xu Bin, 2011; Ettehadi Osgouei \& Kaya, 2017]. Therefore, this research developed a multiple linear regression models to integrate the NDBI with SAVI, NDWI and TIRS.

DKI Jakarta as a capital city of Indonesia is the center of economic activity for all surrounding areas [Pacione, 2005; Syahbana Indraprahasta, 2013]. This circumstance attracts inhabitants to live and work in
DKI Jakarta [Henderson \& Kuncoro, 1996; Firman, 2009; Pravitasari et al., 2015; Rukmana, 2018]. The inhabitants need land for their daily activity i.e. housing, office, industry, and commercial, trigger the land-use/land-cover change and urban sprawling [Firman, 1997; Lestari et al., 2015]. Land-use/landcover change and urban sprawling would be impacted to the quality of environment for example urban heat island, environmental pollution (atmospheric, water, soil), flooding [Wibowo \& Rustanto, 2013; Costa, et al., 2016; Heald \& Geddes, 2016; Murakami et al., 2017; Sutjiningsih, 2017; Effendi et al., 2018]; Hence, it is necessary to develop a methodology for mapping the percent of building density (PBD) to monitor the growth of built-up area in DKI Jakarta. Calculating $\mathrm{PBD}$ is also necessary in particular for semi-automatic mapping of building coverage ratio (BCR) in urban area through remote sensing.

\section{The Methods}

\section{Study Area and Data Collecting}

The area of study is the urban area of DKI Jakarta Province, located at 106.22'42" S and 106.58 '18" $\mathrm{E}$, the total area of study is $661,52 \mathrm{~km} 2$, and the population is more than 10 million. A fullscene Landsat 8 (path 22 row 64) of 2014/9/13 was acquired with a little cloud cover. The very highresolution (VHR) imagery was used to calculate the percentage of a building as training data sample.

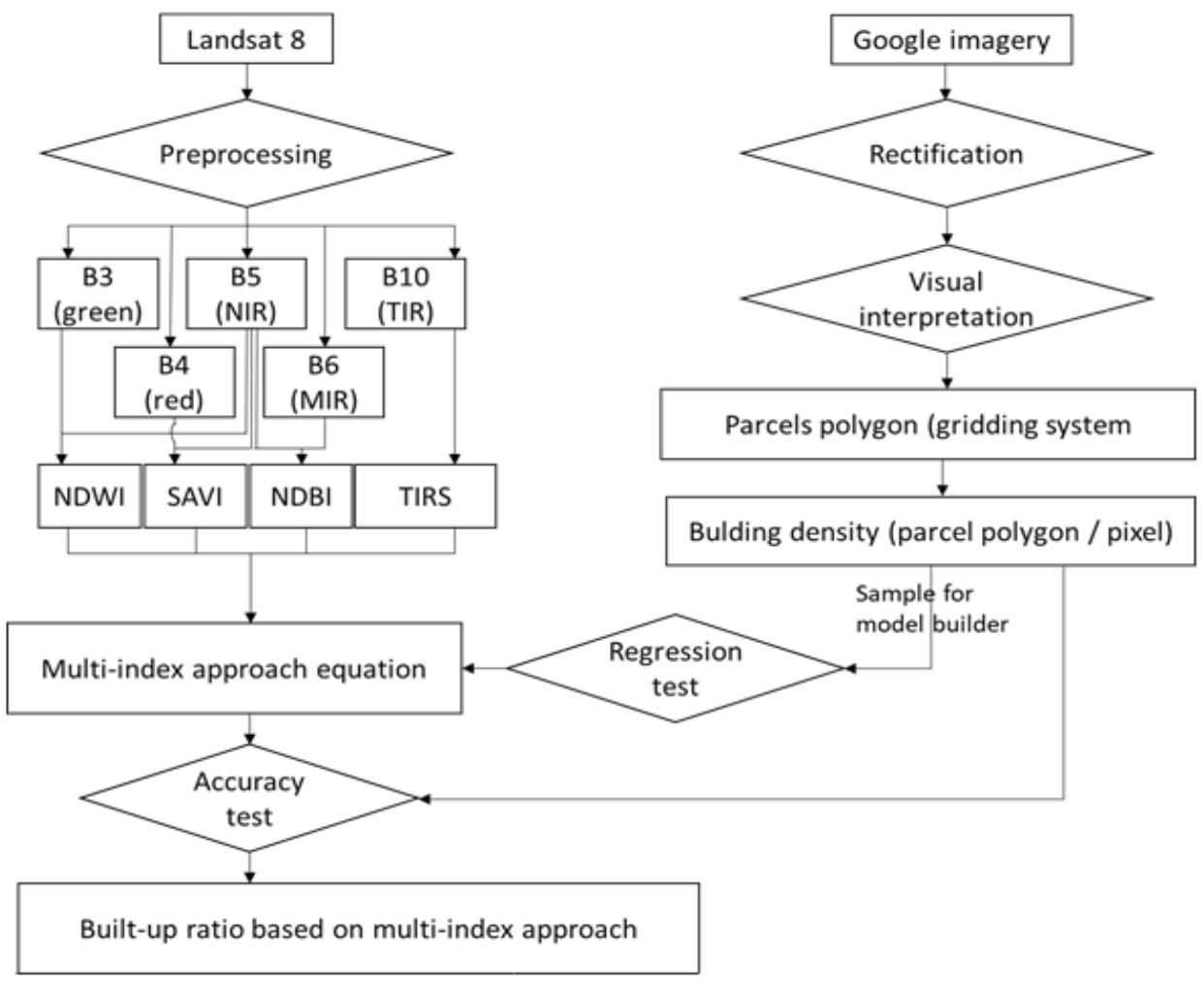

Figure 1. Research Design 


\section{Research Design}

The model was developed using several selected predictor variables that have relevance to the identification of land-use/land-cover objects, such as NDBI, SAVI, NDWI, and TIRS. The four predictor variables are extracted from the Landsat 8 imagery, then the pixel value of the whole variable is compared with the training data sample. The existing built-up area ratio was calculated based on a building interpretation of VHR imagery taken in some locations (see figure 1).

The built-up area object as training data sample was generated from the interpretation of VHR imagery and calculated its percentage by the Landsat pixel $(30 \mathrm{x}$ $30 \mathrm{~m}$ ) by gridding system (see figure 1). VHR imagery is a common, efficient and easy tool to generate training data sample [Rokhmatuloh et al., 2005; Rokhmatuloh et al., 2007; Tsutsumida \& Comber, 2015]. First, VHR imagery was corrected to produce rectified VHR imagery then parcels polygon of building was delineated based on visual interpretation. The calculation of this built-up area is taken from several samples of VHR imagery recorded in several locations in DKI Jakarta Province, calculated by gridding system (see figure 2). 2.103 of $30 \times 30 \mathrm{~m}$ was collected as a training data sample to develop the multi-index model for PBD.

The multi-index approach is used to estimate the percent of building density (PBR) based on the linear regression model as follows: $Y=a_{0}+a_{1} X_{1}+a_{2} X_{2}+a_{3} X_{3}+a_{4} X_{4}$

Where $\mathrm{Y}$ is Percent of building density (PBR) a0, a1, a2, a3, a4 are coefficients; $\mathrm{x} 1$ is NDBI, $\mathrm{x} 2$ is SAVI, $\mathrm{x} 3$ is NDWI, $\mathrm{x} 4$ is TIRS

\section{NDBI Algorithm}

Normalized Difference Built-up Index (NDBI) is an algorithm for estimating the level of built-up area. The principle of this algorithm is for sharpening the building objects by calculating the ratio between midinfrared (MIR) band and near-infrared (NIR) band (see figure 1). Based on its characteristics, the built-up area object reflects the MIR band higher than the NIR band.
However, in some cases, dry soil and built-up area have similar characteristics which the MIR reflectance value is much higher than the NIR wave [Gao, 1996]. The formula for calculating NDBI as follows [Zha et al., 2003]: $N D B I=\frac{M I R-N I R}{M I R+N I R}$

\section{SAVI Algorithm}

Soil-adjusted vegetation index (SAVI) is one of the vegetation index algorithms for calculating ratio between the infrared band and the red band (see figure 1). SAVI is almost similar with Normalized Difference Vegetation Index (NDVI) in terms of use to calculate the greenishness of vegetation. SAVI is more accurate than NDVI for specific areas with low vegetation cover such as urban areas [Almutairi et al., 2013]. The formula for calculating SAVI as follows [Huete, 1988]: $S A V I=\frac{(N I R-R E D)(1+L)}{N I R+R E D+1}$

Where $\mathrm{L}$ is a correction factor valued between 0 and 1 . A value 0 is used if the vegetation density is very high, while the number 1 is used when the density is very low. In this study, the correction factor value used is 0.5 because the study area has vegetation cover with medium density level.

\section{NDWI Algorithm}

The normalized difference water index (NDWI) is an algorithm for identifying the water objects. The algorithm utilizes the green band and infrared band (see figure 1) because the water objects have high reflectance characteristics in the green spectrum and high absorption rates in the near Infrared spectrum. By comparing the values of the two bands, the objects containing water will increase radiometrically when compared to other objects. The formula for calculating NDWI as follows [Gao, 1996]: $N D W I=\frac{G R E E N-N I R}{G R E E N+N I R}$

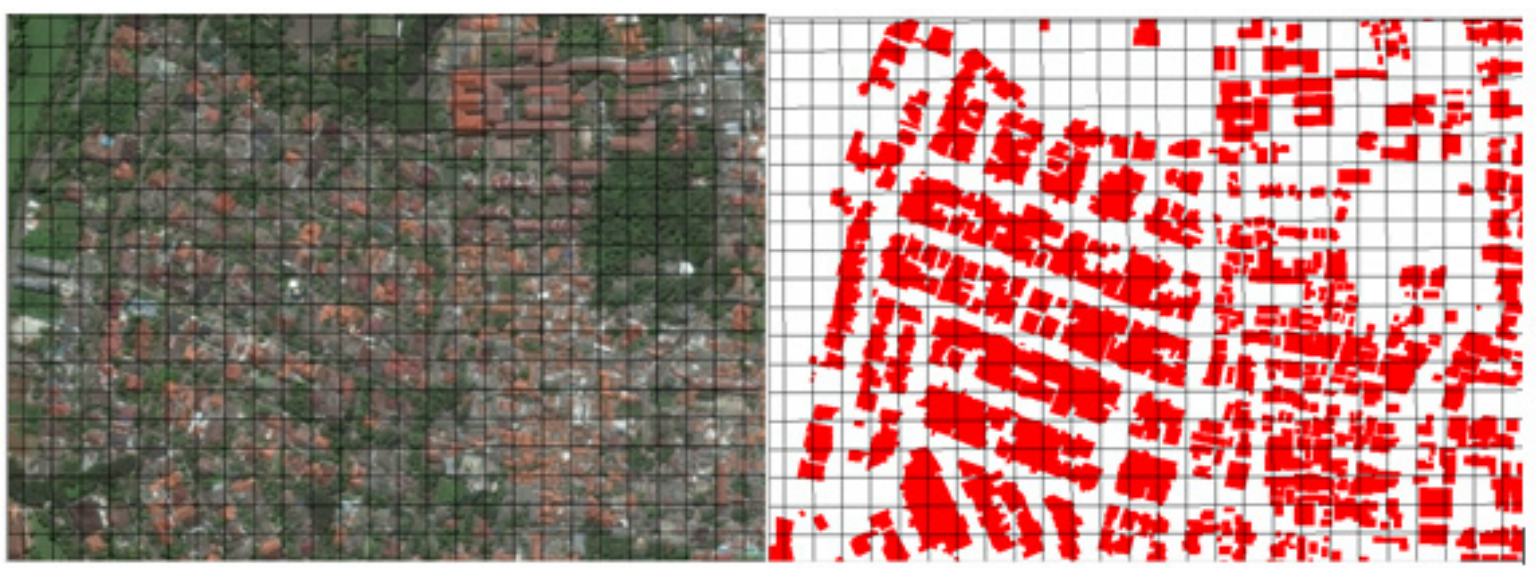

Figure 2. Gridding system for calculation PBD as training sample 


\section{Radiance Band Thermal Algorithm}

One of the Landsat 8 sensors, the Thermal Infrared Sensor (TIRS) records the thermal radiation emitted by objects on the earth surface. Some objects have their own characteristics in emitting the radiation. Built-up area will emit larger radiation than the other objects (vegetation and water). There are two steps for producing the radiance thermal data, the first step is converting the digital number into a specific radiance spectral: $L \lambda=M L * Q c a l+A L$

Where $\mathrm{L} \lambda$ is radiance spectral, $\mathrm{ML}$ is bandspecific multiplicative rescaling factor from the metadata, Qcal is quantized and calibrated standard product pixel value (digital number), and AL is bandspecific additive rescaling factor from metadata. Second step is converting the radiance spectral into a surface temperature (Kelvin):

$T=\frac{K_{2}}{\ln \left(\frac{K_{1}}{L \lambda}+1\right)}$

Where $\mathrm{T}$ is surface temperature (Kelvin), $\mathrm{K} 1$ \& $\mathrm{K} 2$ is constants from the metadata, and $\mathrm{L} \lambda$ is radiance spectral.

\section{Result and Discussion NDBI Value of DKI Jakarta}

The NDBI value has a range from -1 to 1 . The higher NDBI value (close to 1) represents the entire pixel is covered by the building. On the other hand, if the NDBI value of a pixel is low (close to -1$)$, then it

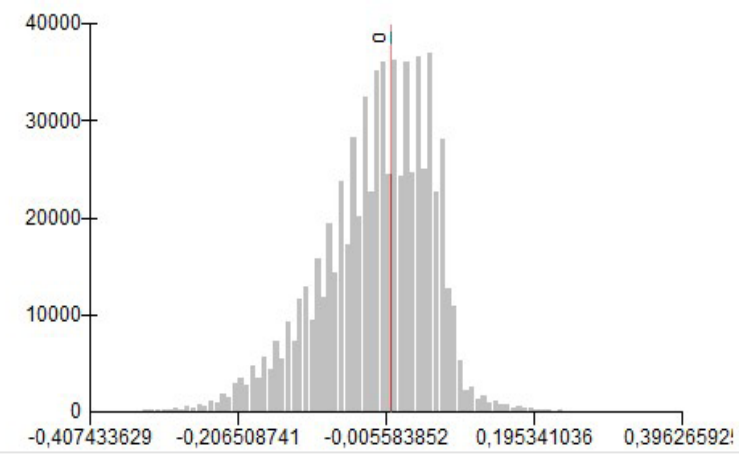

Figure 3. Histogram of NDBI Pixel Value NDWI Value of DKI Jakarta

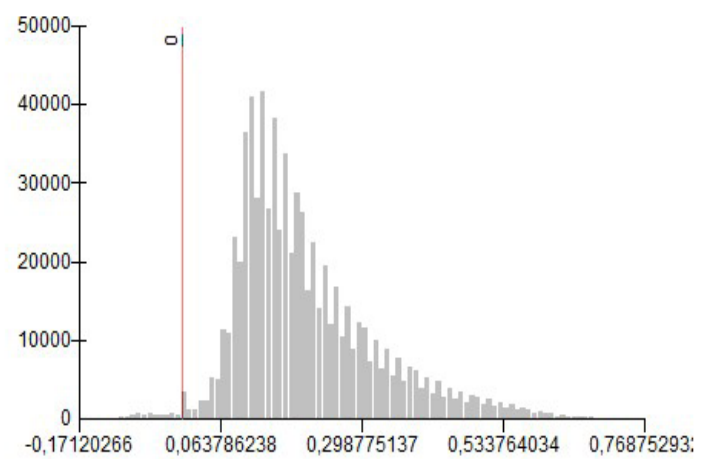

Figure 5. Histogram of SAVI Pixel Value indicates that the existence of the built-up land is very low. The results of processing from Landsat 8 data, the value of NDBI in the DKI Jakarta Province ranged from -0.407 to 0.399 (see figure 3 ). The mean value of NDBI from all regions of DKI Jakarta Province is -0.0189 .

NDWI value the pixel contains an object that has a high humidity level (very wet object). While the lower the NDWI value indicated the pixel contains object that has a high degree of dry. The results of processing from Landsat 8 data, the value of NDWI in the DKI Jakarta Province ranged between -0.451 to 0.167 , while the mean is -0.1309 (see figure 4).

\section{SAVI Value of DKI Jakarta}

The SAVI values range is from -1 to 1 . The higher SAVI value (close to 1) represents the greenness level of pixel, this means there are enough objects to be vegetated within the pixel. While the lower the SAVI value (close to -1) indicates lower greenness level within the pixel. The result of processing shows that SAVI value in DKI Jakarta Province is between $-0,171$ until 0,768 . The mean value of SAVI from all areas of DKI Jakarta Province is 0.205 (see figure 5).

\section{Thermal Index Value of DKI Jakarta}

The sensor in band 11 on the Landsat 8 Satellite is capable to record the radiant heat level emitted from the earth's surface and then translated into an image composed of valuable pixels. Each pixel has a value of 0 22.5. The higher the thermal index value, the higher the

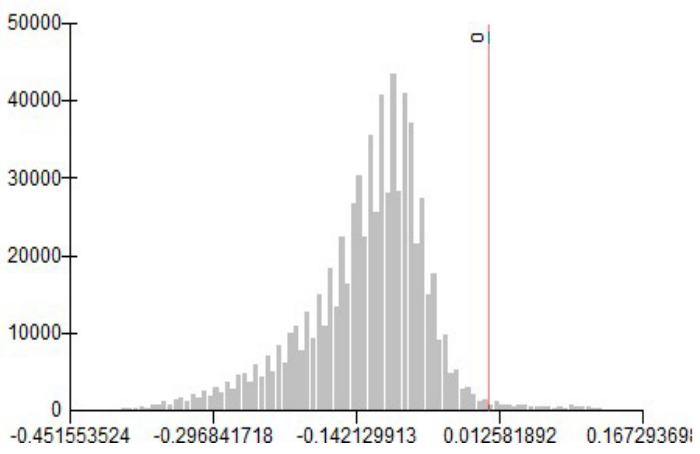

Figure 4. Histogram of NDWI Pixel Value

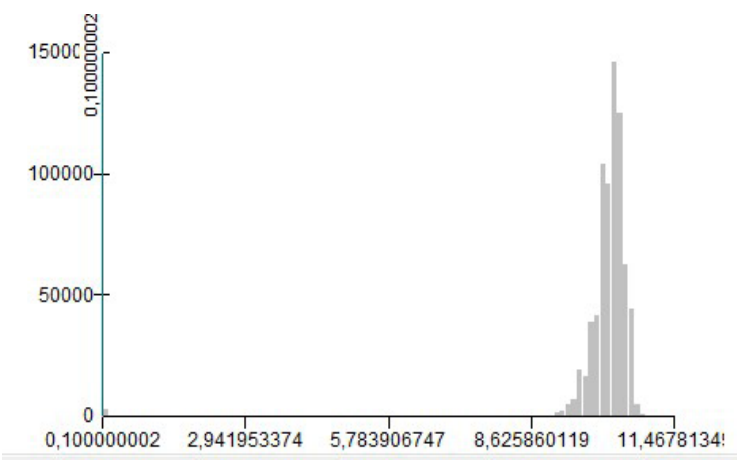

Figure 6. Histogram of Thermal Index Pixel Value 


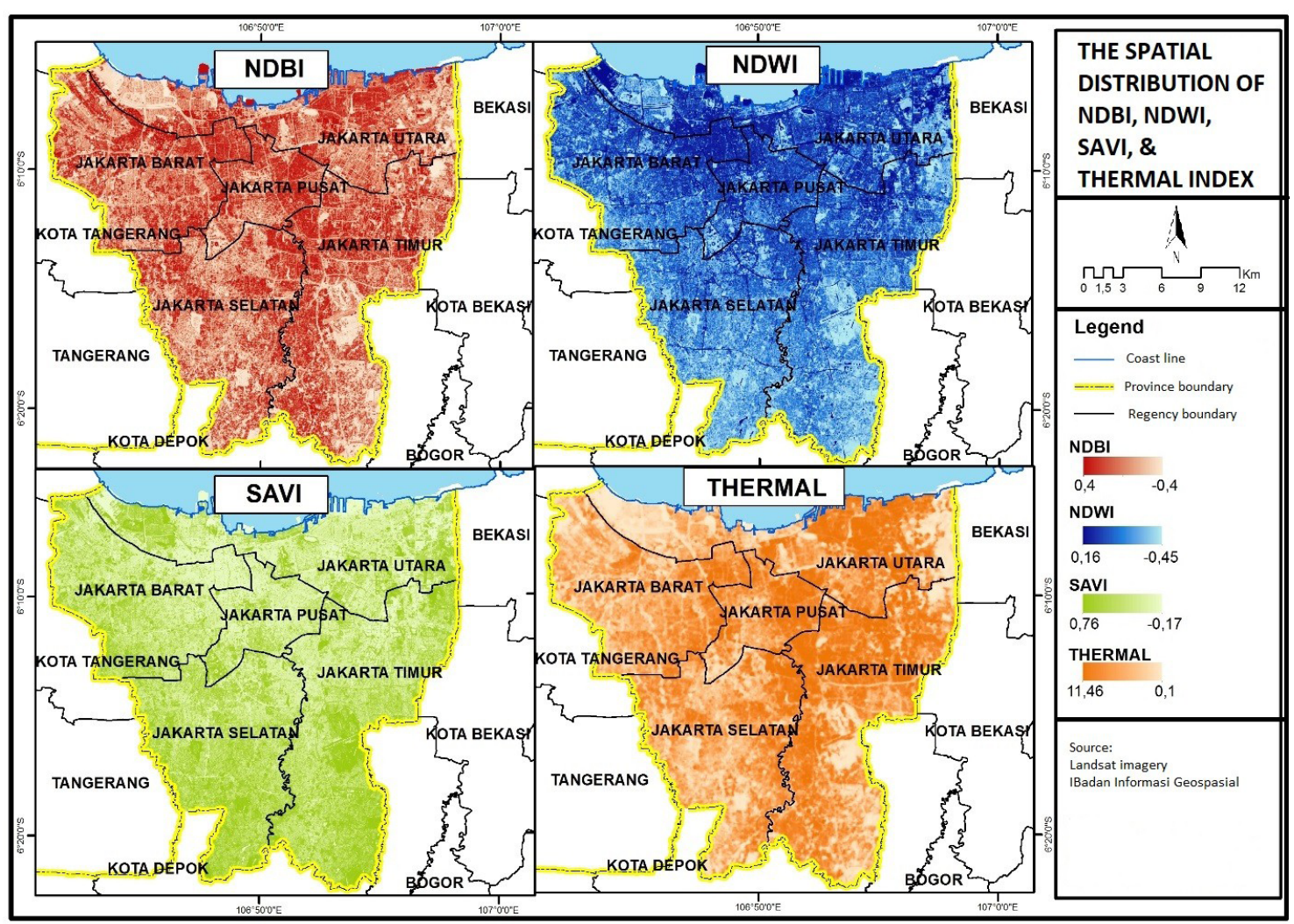

Figure 7. The predictor variables index: NDBI, NDWI, SAVI and thermal radiation index

object emits heat radiation, the lower the thermal index value the lower the heat emitted by the object. The results of processing show that thermal index value in the area of DKI Jakarta Province ranged from 0.1 to 11.467 . The mean value of Thermal Index is 10.16 (see figure 6).

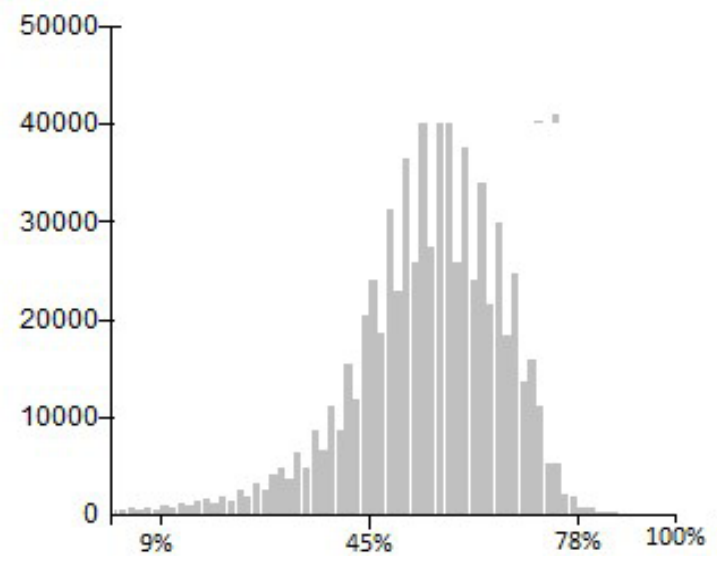

Figure 9. Histogram of Percent of Building Density (PBD)

The Multi-index Model for Percent of Building Density

Each sample of pixels has four predictor variables (NDBI, NDWI, SAVI, thermal) as the predictor variables and the calculation of Percent of Building Density (PBD) from VHR imagery as the dependent variables. The results of Pearson correlation test between PBD model and four predictor variables indicate that there is a strong correlation between the four predictor variables and PBD from VHR imagery. The NDBI, NDWI, and radiance variables are positive correlation, while SAVI has a negative (opposite) correlation. The $\mathrm{R}$ values of predictor variables are significantly correlated where the thermal variable has the highest $\mathrm{R}$ number (see table 1 ).

The result of simple linear regression model shows that the four variables simultaneously have correlation and similar pattern to the PBD based on VHR imagery (see table 2). The Adjusted R Square value is 0,734. It indicates that all four variables influence predicting the percent of building density by $73 \%$ (see table 3 ) while the other $27 \%$ may be influenced by the other variables. The equation for predicting PBD is: $\mathrm{Y}=-488.11+8,343 \times 1+$ $2.2211 \times 2+50.696 \times 3+52.090 \times 4$ Where $\mathrm{Y}$ is Percent of building density (PBD), $\mathrm{x} 1$ is NDBI, $\mathrm{x} 2$ is SAVI, $\mathrm{x} 3$ is NDWI, and $\mathrm{x} 4$ is radiance thermal. This PBD model is used to interpolate the building density throughout the study area (See figure 8). The distribution of pixel percentage value of built-up area ratio is presented in figure 9. It can be seen that the graph increases at $\mathrm{X}=55 \%$, meaning that most of pixels in DKI Jakarta Province are half covered by the building. The most dense is located in Jakarta Pusat because it is a central business district and the Jakarta's core of economic activity, consists of many high-rise building, shopping arcade, 4-5 stars hotels, and high density road network [Asri \& Hidayat, 2005; Leaf, 1996; Susantono, 1998]. The other dense region is located in Jakarta Timur and Jakarta Utara. Jakarta Timur is consist of high-density 
Table 1. Pearson Correlation Test

\begin{tabular}{lllllll}
\hline & PBD & NDBI & NDWI & Thermal & SAVI \\
\hline BAR & Pearson Correlation & 1 &, $633^{* *}$ &, $347^{* *}$ &, $850^{* *}$ &,$- 457^{* *}$ \\
& Sig. (2-tailed) & & 0,000 & 0,000 & 0,000 & 0,000 \\
N & 2103 & 2103 & 2103 & 2103 & 2103 \\
\hline
\end{tabular}

Table 2. ANOVA

\begin{tabular}{lllllll}
\hline Model & Sum of squares & df & $\begin{array}{l}\text { Mean } \\
\text { Square }\end{array}$ & F & Sig & \\
\hline 1 & Regression & 1045973,781 & 4 & 261493,445 & 1453,544 & ,000b \\
& Residual & 377431,527 & 2098 & 179.901 & & \\
& Total & 1423405,309 & 2102 & & & \\
& & & & & & \\
\end{tabular}

Table 3. Model Summary

\begin{tabular}{lllll}
\hline Model & $\mathrm{R}$ & R Square & $\begin{array}{l}\text { Adjusted R } \\
\text { Square }\end{array}$ & Std.Error of the Estimate \\
\hline 1 &, $857 \mathrm{a}$ & 0,735 & 0,734 & 13,4127 \\
\hline \multicolumn{2}{l}{ a. Predictors: (Constant), NDBI, SAVI, NDWI, RADIANCE }
\end{tabular}

Table 4. Coefficients

\begin{tabular}{|c|c|c|c|c|c|}
\hline \multirow[t]{2}{*}{ Model } & \multicolumn{2}{|c|}{ Unstandardized Coefficients } & \multirow{2}{*}{$\begin{array}{l}\text { Standardized } \\
\text { Coefficients } \\
\text { Beta }\end{array}$} & \multirow[t]{2}{*}{$\mathrm{t}$} & \multirow[t]{2}{*}{ Sig } \\
\hline & $\mathrm{B}$ & Std. Error & & & \\
\hline (Constant) & $-488,111$ & 12,627 & & $-38,655$ &, 000 \\
\hline NDBI & 8,343 & 6,683 &, 028 & 1,249 &, 212 \\
\hline NDWI & 50,696 & 34,019 & ,125 & 1,49 & ,136 \\
\hline RADIANCE & 52,090 & 1,225 & ,797 & 42,539 &, 000 \\
\hline SAVI & 2,211 & 20,860 & 009 & ,106 & ,916 \\
\hline
\end{tabular}

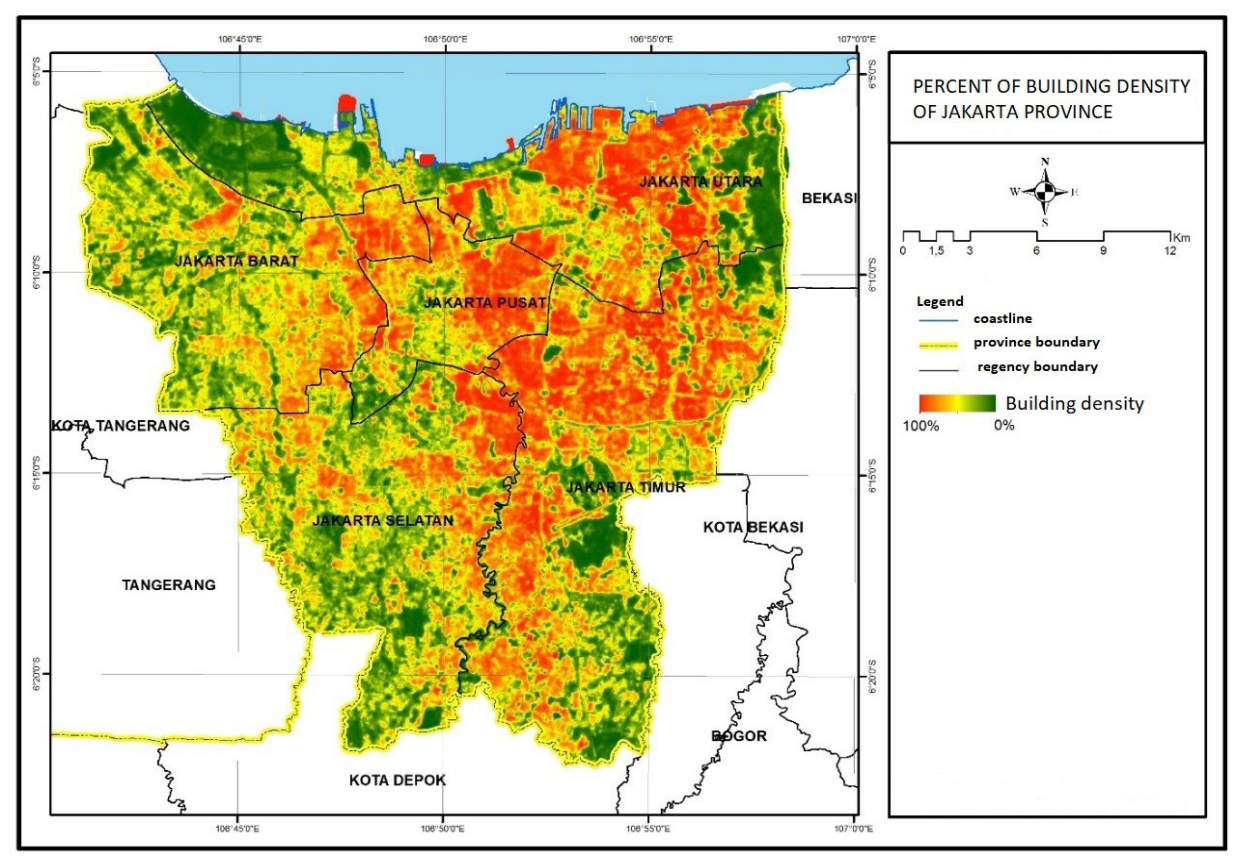

Figure 8. PBD Map of Jakarta Province 
settlement area and also industrial agglomeration while Jakarta Utara particularly Tanjung Priok is the busiest port in Indonesia that contains many containers [Yudhistira \& Sofiyandi, 2017]. Near Tanjung Priok, there is also high-density settlement area known as kampung for port worker and fishermen [Baum et al., 2016; Prabowo, Suprapto, \& Oswari, 2008; Silver, 2018]. The other high-density is located on the border of Jakarta Timur and Jakarta Selatan. The border of Jakarta Timur and Jakarta Selatan is Ciliwung river where along its riverbank is occupied by high-density informal settlement [Steinberg, 2007; Vollmer \& GrêtRegamey, 2013; Vollmer et al., 2015; Winarso, 2011].

\section{Conclusion}

The multi-index approach for percent of building density (PBD) mapping of DKI Jakarta Province based on Normalized Difference Built Index (NDBI), Soil-adjusted Vegetation Index (SAVI), Normalized Difference Water Index (NDWI), and thermal Index shows a sufficiency adjusted $r$-squared result. For the next research, improving the adjusted $r$-squared result will be considered using another statistics model i.e. multiple regression with logarithmic transformation, exponential transformation, and polynomial transformation or machine learning approach. The PBD mapping algorithm is very important for another urban environment baseline research for example city planning, disaster prevention and mitigation, transportation and infrastructure planning, or even slum area mapping.

\section{Acknowledgement}

The author would like to thank the financial support from Department of Geography, Faculty of Mathematics and Natural Science, Universitas Indonesia through "Hibah Penelitian Pemula 2014". Special thank to Infimap Geospasial Sistem that provided another valuable funding through "The Development of Remote Sensing Techniques for socio-demographic data acquisitions" research grants.

\section{References}

Almutairi, B., El battay, A., Ait Belaid, M., \& Musa, N. (2013). Comparative study of SAVI and NDVI vegetation indices in Sulaibiya Area (Kuwait) using Worldview satellite imagery. International Journal of Geosciences and Geomatics, 1(2), 2052-5591.

Bhatti, S. S., \& Tripathi, N. K. (2014). Built-up area extraction using Landsat 8 OLI imagery. GIScience \& Remote Sensing, 51(4), 445-467. https://doi.org/10.1080/15481603.2014.939539

Costa, D., Burlando, P., \& Priadi, C. (2016). The importance of integrated solutions to flooding and water quality problems in the tropical megacity of Jakarta. Sustainable Cities and Society, 20, 199209. https://doi.org/10.1016/J.SCS.2015.09.009

Effendi, H., Sabila, M. F., \& Setiawan, Y. (2018).
Correlation between water quality and land use change in Ciliwung watershed. Nature Environment and Pollution Technology, 17(1), 139-144.

Firman, T. (1997). Land conversion and urban development in the northern region of West Java, Indonesia. Urban Studies, 34(7), 10271046. https://doi.org/10.1080/0042098975718

Firman, T. (2009). The continuity and change in mega-urbanization in Indonesia: A survey of Jakarta-Bandung Region (JBR) development. Habitat International, 33(4), 327-339. https:// doi.org/10.1016/J.HABITATINT.2008.08.005

Gao, B. (1996). NDWI-A normalized difference water index for remote sensing of vegetation liquid water from space. Remote Sensing of Environment, 58(3), 257-266. https:// doi.org/10.1016/S0034-4257(96)00067-3

Heald, C. L., \& Geddes, J. A. (2016). The impact of historical land use change from 1850 to 2000 on secondary particulate matter and ozone. Atmospheric Chemistry and Physics, 16, 1499715010. https://doi.org/10.5194/acp-16-14997-2016

Huete,A..(1988).Asoil-adjustedvegetationindex(SAVI). Remote Sensing of Environment, 25(3), 295-309. https://doi.org/10.1016/0034-4257(88)90106-X

Lestari, S., Moersidik, S. S., \& Syamsudin, F. (2015). Study on heat island effect induced by land use change increased temperature in metropolitan Jakarta. Journal of Mathematical and Fundamental Sciences (Vol. 47). Retrieved from http://journals. itb.ac.id/index.php/jmfs/article/view/437/849

Maktav, D., Erbek, F. S., \& Jürgens, C. (2005). Remote sensing of urban areas. International Journal of Remote Sensing, 26(4), 655-659. https://doi.org/10.1080/01431160512331316469

Masek, J. G., Lindsay, F. E., \& Goward, S. N. (2000). Dynamics of urban growth in the Washington DC metropolitan area, 19731996, from Landsat observations. International Journal of Remote Sensing, 21(18), 3473-3486. https://doi.org/10.1080/014311600750037507

Murakami, A., Kurihara, S., Harashina, K., \& Zain, A. M. (2017). Features of Urbanization and Changes in the Thermal Environment in Jakarta, Indonesia (pp. 61-71). Springer, Tokyo. https://doi.org/10.1007/978-4-431-56445-4_6

Pacione, M. (2005). Urban Geography: A Global Perspective (2nd ed.). Taylor \& Francis.

Pravitasari, A. E., Saizen, I., Tsutsumida, N., Rustiadi, E., \& Pribadi, D. O. (2015). Local spatially dependent driving forces of urban expansion in an emerging Asian megacity: The case of Greater Jakarta (Jabodetabek). Journal of Sustainable Development, 8(1). $\quad$ https://doi.org/10.5539/jsd.v8n1p108 Rokhmatuloh, Nitto, D., Al Bilbisi, H., Arihara, K., \& Tateishi, R. (2007). Estimating percent tree cover using regression tree method with veryhigh-resolution Quickbird images as training 
data. Journal of the Remote Sensing Society of Japan, 1, 1-12. Retrieved from https://www. jstage.jst.go.jp/article/rssj/27/1/27_1_1/_pdf Rokhmatuloh, Nitto, D., Al Bilbisi, H., \& Tateishi, R. (n.d.). Percent tree cover estimation using regression tree method: a case study of Africa with very-high resolution QuickBird images as training data. In Proceedings. 2005 IEEE International Geoscience and Remote Sensing Symposium, 2005. IGARSS '05. (Vol. 3, pp. 2157-2160). IEEE. https://doi.org/10.1109/IGARSS.2005.1526445

Rukmana, D. (2018). Rapid urbanization and the need for sustainable transportation policies in Jakarta. IOP Conference Series: Earth and Environmental Science, 124. https:// doi.org/10.1088/1755-1315/124/1/012017

Sutjiningsih, D. (2017). Water quality index for determining the development threshold of urbanized catchment area in Indonesia. International Journal of Technology, 1, 145159. https://doi.org/10.14716/ijtech.v8i1.3971

Syahbana Indraprahasta, G. (2013). The potential of urban agriculture development in Jakarta. Procedia Environmental Sciences, 17, 11-19. https://doi.org/10.1016/j.proenv.2013.02.006
Tsutsumida, N., \& Comber, A. J. (2015). Measures of spatio-temporal accuracy for time series land cover data. International Journal of Applied Earth Observation and Geoinformation, 41, 46-55. https://doi.org/10.1016/J.JAG.2015.04.018

Waqar, M. M., Mirza, J. F., Mumtaz, R., \& Hussain, E. (2012). Development of new indices for extraction of built-Up area \& bare soil from Landsat data. Open Acess Scientific Reports, 1(1). https://doi.org/10.4172/scientificreports.136 Wibowo, A., \& Rustanto, A. (2013). Spatial-temporal analysis of urban heat island in Tangerang City. Indonesian Journal of Geography, 45(2), 101-115. https://doi.org/10.22146/IJG.4867

Xu,H.(2007).Extraction of Urban Built-upLandFeatures from Landsat Imagery Using a Thematic-oriented Index Combination Technique. Photogrammetric Engineering \& Remote Sensing, 12, 1381-1391.

Zha, Y., Gao, J., \& Ni, S. (2003). Use of normalized difference built-up index in automatically mapping urban areas from TM imagery. International Journal of Remote Sensing, 24(3), 583-594. https://doi.org/10.1080/01431160210144570 